DEPARTMENT OF THE INTERIOR

U.S. GEOLOGICAL SURVEY

MAPS SHOWING CUMULATIVE DAMAGE POTENTIAL FROM

EARTHQUAKE GROUND SHAKING, SAN MATEO COUNTY, CALIFORNIA

By Jeanne B. Perkins

MISCELLANEOUS INVESTIGATIONS SERIES

Published by the U.S. Geological Survey, 1987 


\title{
CUMULATIVE DAMAGE POTENTIAL FROM EARTHQUAKE GROUND SHAKING, SAN MATEO COUNTY, CALIFORNIA
}

\author{
By Jeanne B. Perkins
}

\begin{abstract}
INTRODUCTION
During the next few decades there will be many earthquakes that affect the San Francisco Bay area, which includes San Mateo County. To plan for emergencies and to mitigate potential hazards, planners and other decisionmakers need information about the potential effects of earthquakes in various locations of the county. Although maps can be produced that show predicted intensities from a single hypothetical event, such as a repeat of the 1906 San Francisco earthquake, composite maps can show the cumulative damage potential from earthquakes on all faults that can affect any location in the area.
\end{abstract}

The first step in creating a composite map is to produce a series of intensity maps, one for each of the 31 active faults in the bay area. Such a series of maps would be unwieldy and potentially confusing to use, but the maps could be combined in two ways to serve two different purposes. (1) A map showing the maximum intensity that might be experienced from all possible fault sources can be compiled by using the highest intensity for every area from each of the individual fault-intensity maps. (2) A map showing the percentage (discounted to present value) of the cumulative damage potential from many different earthquakes over a period of time can be compiled by weighting the intensity maps for individual faults using data on earthquake recurrence rates and damage statistics for hypothetical building types. The difference between the two types of maps becomes apparent if one looks at two areas, one near a fault and one on the unconsolidated geologic materials next to the bay. On a maximum ground shaking intensity map, the two sites may appear equivalent. Yet on any of the cumulative damage potential maps, the site next to the bay is shown having a far greater potential for damage; the fault site is only subject to violent shaking if that fault is the source of shaking, while the site next to the bay is subject to very strong or violent shaking if any of a number of faults are the earthquake source.

A maximum-intensity map can be used with information about existing buildings to forecast locations of maximum damage when planning emergency response measures and designating areas of critical concern. Cumulative-damage-potential maps can be used in making general land-use decisions, in helping to evaluate the relative costs for new earthquake-resistant buildings and to designate areas where special subdivision-design precautions may be needed. However, the damage-potential information is not detailed enough to make engineering decisions about a specific site, for these decisions require specific knowledge of the process that causes damage. These maps do not include any information on existing land use or building type and age. They cannot be used alone in making estimates of current property at risk. They indicate the loss potential inherent in a particular area if a specific type of building is located there. A rough estimate can be made of residential property at risk, for example, by combining data on the map for wood-frame dwellings with other information on residential land use and building type and age.

This report examines the data needed to produce a preliminary series of individual intensity maps and the additional data needed to combine these maps and to produce the composite maps that show cumulative damage potential. The production of the maximumintensity maps has been described elsewhere (Borcherdt and others, 1975). The data for the individual maps include:

1. Location of those faults from which significant ground shaking can originate;

2. The maximum magnitude earthquake that could originate on each active fault, based on the length of that fault and the character of its movement;

3. The maximum intensity experienced in an earthquake of a given magnitude;

4. The attenuation (decrease) of intensity in a standard bedrock material (that is, the Franciscan assemblage) as the distance increases from the fault trace (a) for a maximum event (such as the 1906 San Francisco earthquake) and (b) for smaller events; and

5. The effect of local geology on intensity, using the concept of intensity increments to define seismically distinct groups of geologic materials.

Additional data are needed to combine the individual fault-intensity maps into maps depicting cumulative damage potential:

1. The damage to various types of buildings for various intensities of shaking;

2. The relative activity of faults (based on long-term slip rates);

3. The possible distribution of large- and smallmagnitude events on each fault; and

4. The expected cost of damage as discounted to present value.

The calculations and mapping procedures for the resulting maps made use of the Bay Area Spacial Infor mation System (BASIS), a computer-based geographic information system developed by the Association of Bay Area Governments (ABAG). Use of this computer data base made the manipulation of these many variables manageable.

\section{ACKNOWLEDGMENTS}

Paul Wilson, the president of Geogroup Corporation, is responsible for most computer programming. Other 
participants in the digitizing of maps and userprogramming tasks include Annie Ebert, Malcolm Gilmour, Roberta Moreland, Ruth Robinson, and Paula Schulz, of Geogroup Corporation and the Association of Bay Area Governments.

Special thanks are given to the following individuals for their assistance: Roger Borcherdt, Earl Brabb, Tom Fumal, Jim Gibbs, Ed Helley, Darrell Herd, Bill Kockleman, and Bob Page of the U.S. Geological Survey; Jim Baker, Jim Berkland, and Al Neufeld, staff geologists of various bay area counties; Karl Steinbrugge, consulting structural engineer; and Douglas Detling of the Association of Bay Area Governments.

The preparation of the maps and report was funded in large part by contracts with the U.S. Geological Survey.

\section{ESTABLISHING FAULT ACTIVITY}

The major faults that are mapped as potential sources of ground shaking within San Mateo County were selected from several publications with data about active and potentially active faults in the bay area. Among the most comprehensive sources are (a) maps of the Alquist-Priolo Special Studies Zones (California Division of Mines and Geology, 1974-1983), (b) a fault map of California (Jennings, 1975), (c) a report about faults and future earthquakes in the bay area (Wesson and others, 1975), and (d) several miscellaneous maps and reports (Herd and Helley, 1977; Helley and Herd, 1977; and Herd, 1977, 1978a, 1978b, and oral commun., 1979, 1981, and 1983). Although the fault data in those publications are similar, differences necessitated the preparation of a new list for this project (table 1). The list consists of those faults appearing in all four compilations (a-d). Because more weight was given to the recent work of Herd and others at the U.S. Geological Survey (d), all faults included in (d) were included in this project. Any fault not included in (d) had to be included in all of the first three sources (a-c) in order to be included in this project. This process of choosing faults resulted in the selection of the 31 faults listed in table 1.

Locations of most faults were compiled from the $1: 24,000$-scale maps issued in compliance with the Alquist-Priolo Special Studies Zones Act (California Division of Mines and Geology, 1974-1982). Underwater fault segments were extrapolated from those maps when possible. The underwater segment of the San Andreas and San Gregorio faults outside San Francisco Bay were estimated from Jennings (1975). Other fault locations were taken from recent publications (table 1).

\section{ESTIMATING MAGNITUDE AND INTENSITY Maximum magnitude and intensity on active faults}

The maximum magnitude of a probable earthquake can be inferred from the mapped length of an active fault. The length, the type of faulting, the estimated maximum magnitude and intensity, and the age of faulting of individual faults in the bay area are given in table 1 . The maximum magnitudes were calculated by using the following relations between rupture length and magnitude for various types of faults, (Slemmons, 1977, p. 96). For strike-slip faults,

$$
M=0.597+1.351 \log R \text {, }
$$

where $M$ is the earthquake magnitude and $R$ is the rupture length (in meters). For normal faults,

$$
M=1.845+1.151 \log R
$$

and for reverse and thrust faults,

$$
M=4.145+0.717 \log R
$$

Although these formulas use four significant figures to reduce mathematical error, the calculated magnitudes have only two significant figures because of uncertainties in the formulas. The length of fault rupture typically chosen for use in the above formulas is onehalf the total mapped length. However, because the half-length basis is not universally accepted, maximum magnitudes were also calculated using the total mapped length.

The maximum modified Mercalli intensity (MMI) for any given magnitude of earthquake can be calculated from the following commonly used formula (see, for example, Algermissen and Steinbrugge, 1978):

$$
M M I_{\max }=1.5 M-1.5 \text {. }
$$

The maps of individual intensity and cumulative damage potential were produced by using the maximum intensity and magnitude calculated for onehalf of the total mapped fault length.

\section{Attenuation relation between intensity and distance}

A formula to predict the intensity of ground shaking on bedrock must relate attentuation (the decrease) of intensity to increased distance from the fault for a standard bedrock material. The formula used in the bay area relates San Francisco intensity (SFI) to distance from the fault ( $D$, in kilometers) for the Franciscan assemblage. The formula, developed by Borcherdt and others (1975) is:

$$
S F I=2.69-1.9 \log D .
$$

In the formula, the San Francisco intensity ranges of $A$ to $E$ are expressed numerically as 4 to 0 .

This formula is illustrated (fig. 1). The relation between the San Francisco intensity scale and the more commonly used modified Mercalli intensity scale is shown (fig. 2). The San Francisco intensity scale has been used in this work because the attenuation relation is based on data from the 1906 San Francisco earthquake.

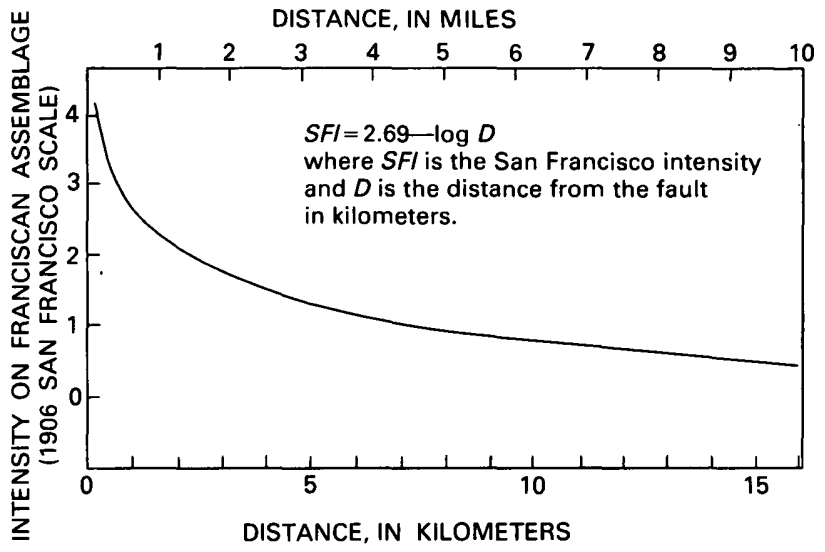

Figure 1.-Attenuation curve for relation between intensity and distance, modified from Borcherdt and others (1975). 
Table 1.-Data on major active and potentially active faults in the San Francisco Bay area, California

\begin{tabular}{|c|c|c|c|c|c|c|c|}
\hline \multirow{2}{*}{ Fault } & \multirow{2}{*}{$\begin{array}{l}\text { Source of fault } \\
\text { trace location used } \\
\text { for this report }\end{array}$} & \multirow{2}{*}{$\begin{array}{r}\text { Length } \\
\text { used here } \\
\text { (L) (ka) }\end{array}$} & \multirow{2}{*}{$\begin{array}{l}\text { Character of } \\
\text { motton or type } \\
\text { of faultting }\end{array}$} & \multicolumn{2}{|c|}{$\begin{array}{l}\text { Maximum magnitude } \\
\text { (Richter Scale) }\end{array}$} & \multicolumn{2}{|c|}{$\begin{array}{l}\text { Maximum intensity } \\
\text { (calculated) converted to } \\
\text { modified Mercalli scale }\end{array}$} \\
\hline & & & & $\begin{array}{l}\text { Based on } \\
1 / 2 L \text { (used } \\
\text { In analysis) }\end{array}$ & $\begin{array}{l}\text { Based on } \\
1 \mathrm{~L} \text { (cal- } \\
\text { culated for } \\
\text { comparison) }\end{array}$ & $\begin{array}{l}\text { Based on } \\
1 / 2 L \text { (used } \\
\text { in analysis) }\end{array}$ & $\begin{array}{r}\text { Based on } \\
1 \mathrm{~L} \text { (cal- } \\
\text { culated for } \\
\text { comparison) }\end{array}$ \\
\hline San Andreas ${ }^{1}$ & $\begin{array}{l}\text { Calit. Div. Mines \& Geology, 1974-83; } \\
\text { Jennings, } 1975\end{array}$ & 1,200 & Right-slip & 8.4 & $\left({ }^{2}\right)$ & $(11.1) / x \mathrm{I}$ & $(11.7) \times x \mid I$ \\
\hline Hollister-Bollnas & $\begin{array}{l}\text { Calif. Div. Mines \& Geology, 1974-83; } \\
\text { Jennings, } 1975\end{array}$ & 160 & Right-slip & 7.2 & 7.6 & $(9.3) \mathrm{nX}$ & $(9.9) / x$ \\
\hline Bollnas-Cape Mendocino & Callt. Div. Mines \& Geology, 1974-83 & 270 & Right-slip & 7.5 & 7.9 & $(9.75) / \mathrm{x}$ & $(10.4) / x$ \\
\hline Calaveras $^{2}$ & $\begin{array}{l}\text { Callf. Div. Mines \& Geology, 1974-83; } \\
\text { Herd, 1978b }\end{array}$ & 170 & Right-slip & 7.3 & 7.7 & $(9.45) / \mathrm{AX}$ & $(10.1) / x$ \\
\hline Colaveras-Palcines & Callf. Div. Mines \& Geology, 1974-83 & 100 & Right-slip & 6.9 & 7.4 & $(8.85) / \mathrm{nx}$ & $(9.6) / x$ \\
\hline Calaveras-Sunol & $\begin{array}{l}\text { Callf. Div. Mines \& Geology, 1974-83; } \\
\text { Herd, 1978b }\end{array}$ & 70 & Right-slip & 6.7 & 7.1 & $(8.55) / \mathrm{x}$ & (9.15)/XX \\
\hline Pleasanton & Callf. Div. Mines \& Geology, 1974-83 & 9 & Right-sllp & 5.5 & 5.9 & 16.75/NII & $(7.35) \mathrm{NII}$ \\
\hline Concord/Green Volley & Callf. Div. Mines \& Geology, 1974-83 & 110 & Right-sllp & 7.0 & 7.4 & $(9.0) / \mathrm{x}$ & $(9.6) / x$ \\
\hline Antloch & Callt. Div. Mines \& Geology, 1974-83 & 37 & Right-slip & 6.4 & 6.8 & (8.1) $\mathrm{NIII}$ & $(8.7) / \mathrm{x}$ \\
\hline Hayward (Incl. Crosley) & Callf. Div. Mines \& Geology, 1974-83 & 90 & Right-slip & 6.9 & 7.3 & $(8.85) / \mathrm{X}$ & $(9.45) / \mathrm{X}$ \\
\hline Healdsburg/Rodgers Creek & Calif. Div. Mines \& Geology, 1974-83 & 72 & Right-slip & 6.8 & 7.2 & $(8.7) n \mathrm{x}$ & $(9.3) 11 \mathrm{x}$ \\
\hline Maacama $^{3}$ & $\begin{array}{l}\text { Herd and Helley, 1977; } \\
\text { Calit. Div. Mines \& Geology, 1974-83; }\end{array}$ & 140 & Right-slip & 7.1 & 7.5 & $(9.15) / \mathrm{XX}$ & $(9.75) / x$ \\
\hline San Gregorio & $\begin{array}{l}\text { Green and others 1973: Jennings, 1975; } \\
\text { Calif. Div. Mines \& Geology, 1974-83; }\end{array}$ & 140 & Right-slip & 7.1 & 7.5 & $(9.15) \cap \mathrm{X}$ & $(9.75) / \mathrm{X}$ \\
\hline Verona & Herd, 1977 & 10 & Thrust & 6.8 & 7.0 & (8.7) $\mathrm{nX}$ & $(9.0) \pi \mathrm{x}$ \\
\hline Silver Creek & $\begin{array}{l}\text { Santa Clara County, 1978; } \\
\text { Callf. Div. Mines \& Geology, 1974-83 }\end{array}$ & 30 & Thrust & 7.1 & 7.3 & $(9.15) n \mathrm{nX}$ & $(9.45) / \mathrm{X}$ \\
\hline Evergreen & Calif. Div. Mines \& Geology, 1974-83 & 14 & Thrust & 6.9 & 7.1 & $(8.85) \pi \mathrm{x}$ & $(9.15) / \mathrm{X}$ \\
\hline Dunnigan Hills & Helley and Herd, 1977 & 10 & Reverse & 6.8 & 7.0 & $(8.7) / \mathrm{x}$ & $(9.0) \pi \mathrm{x}$ \\
\hline West Napa & Helley and Herd, 1977 & 28 & Right-slip & 6.2 & 6.6 & (7.8) NIII & (8.4) NIII \\
\hline Cordellis & Helley and Herd, 1977 & 19 & Right-slip & 5.9 & 6.4 & $(7.35) \mathrm{NII}$ & $(8.1) / \mathrm{NIII}$ \\
\hline Sargent (north of $-37^{\circ}$ lat.) & Santa Clara County, 1978 & 20 & Normal & 6.4 & 6.8 & (8.1) NIII & $(8.7) / \mathrm{x}$ \\
\hline Sargent (south of $-37^{0}$ lat.) & Santa Clara County, 1978 & 17 & Right-slip & 5.9 & 6.3 & $(7.35) \mathrm{NII}$ & (7.95) NIII \\
\hline Las Positas & Herd, 1977 & 14 & Normal & 6.3 & 6.6 & (7.95) NIII & (8.4) NIII \\
\hline Greenville & Calif. Div. Mines \& Geology, 1974-83 & 50 & Normal & 6.9 & 7.3 & $(8.85) / \mathrm{Ax}$ & $(9.45) / \mathrm{x}$ \\
\hline Faults near Trenton & Herd and Helley, 1977 & 27 & Right-slip & 6.2 & 6.6 & (7.8) NIIII & (8.4/NIIII \\
\hline Tolay & Callif. Div. Mines \& Geology, 1974-83 & 11 & Right-slip & 5.7 & 6.1 & $(7.05) \mathrm{NII}$ & $(7.65) \mathrm{NIII}$ \\
\hline $\begin{array}{l}\text { Faults east of Bennett } \\
\text { Volley and Santa Rosa }\end{array}$ & $\begin{array}{l}\text { Helley \& Herd, 1977; } \\
\text { Herd \& Helley, } 1977\end{array}$ & 10 & Thrist & 6.8 & 7.0 & $(8.7) / \mathrm{x}$ & $(9.0) \mathrm{nX}$ \\
\hline Zayante & Hall and others, 1974 & 82 & Mght-stp & 6.8 & 7.2 & $(8.7) / \mathrm{x}$ & $(9.3) \wedge x$ \\
\hline Berrocal & Sorg and McLaughlin, 1975 & 60 & Thrust & 7.4 & 7.6 & $(9.6) / x$ & $(9.9) / x$ \\
\hline Midway & Herd, written commun., 1983 & 10 & Reverse & 6.8 & 7.0 & $(8.7) / \mathrm{x}$ & $(9.0) \pi \mathrm{x}$ \\
\hline San Joaquin & Herd, written commun., 1983 & 120 & Normal & 7.3 & 7.8 & $(9.45) / 1 \mathrm{X}$ & $(10.2) / x$ \\
\hline Monte Vista & Santa Clara County, 1978 & 30 & Thrust & 7.1 & 7.4 & $(9.15) / \mathrm{x}$ & $(9.6) / x$ \\
\hline Coyote Creek & Callf. Div. Mines \& Geology, 1974-83. & 10 & Thrust & 6.8 & 7.0 & $(8.7) \pi \mathrm{x}$ & $(9.0) / x$ \\
\hline Plercy & Callf. Div. Mines \& Geology, 1974-83 & 3 & Thrust & 6.4 & 6.6 & (8.1)/NIII & (8.4) NIII \\
\hline Serra & Callf. Div. Mines \& Geology, 1974-83 & 11 & Thrust & 6.8 & 7.0 & $(8.7) / \mathrm{x}$ & $(9.0) \pi \mathrm{x}$ \\
\hline Ortigalita & Herd, wrttten commun., 1983 & 27 & Right-slip & 6.2 & 6.6 & (7.8) $/ \mathrm{NIII}$ & (8.4) NIII \\
\hline
\end{tabular}




\begin{tabular}{|c|c|}
\hline $\begin{array}{c}\text { San } \\
\text { Francisco } \\
\text { scale }\end{array}$ & $\begin{array}{c}\text { Modified } \\
\text { Mercalli } \\
\text { scale }\end{array}$ \\
\hline \multirow{2}{*}{$\begin{array}{c}\text { A } \\
\text { (Very violent) }\end{array}$} & XII \\
\hline & $x I$ \\
\hline \multirow{2}{*}{$\begin{array}{c}\text { B } \\
\text { (Violent) }\end{array}$} & $x$ \\
\hline & IX \\
\hline \multirow[b]{2}{*}{$\begin{array}{c}\text { C } \\
\text { (Very strong) }\end{array}$} & \multirow[t]{2}{*}{ VIII } \\
\hline & \\
\hline \multirow{2}{*}{$\begin{array}{c}\text { D } \\
\text { (Strong) }\end{array}$} & VII \\
\hline & \multirow{2}{*}{ VI } \\
\hline$\underset{\text { (Weak) }}{E}$ & \\
\hline
\end{tabular}

Figure 2.-Approximate relation between intensity scales, modified from Wood (1908, p. 220-245) and Wood and Neumann (1931, p. 277-283).
Bedrock intensity maps for earthquakes on faults shorter than the San Andreas need to be adjusted to account for events smaller than the 1906 earthquake. The relation between maximum intensity (nearest the fault) and maximum magnitude is shown above. Other intensities are assumed to have the same attenuation relation as those for a 1906 event, but they should be adjusted downward. With this system, the isoseismal or geographic boundaries remain the same but are relabeled as zones of lower intensities. The zone closest to the fault (shown as $A$ on table 4) would be relabeled as $B$ for an earthquake with a maximum intensity of $B$. The next zone, shown as $B$, would be relabeled as $C$, and so on.

Correcting the attenuation formula for geology

Different intensities may occur at sites that are located the same distance from a fault but are on different types of geologic materials. To correct the general formula for intensity on the Franciscan assemblage to apply to other geologic materials, an intensity increment must be added to, or subtracted from, the derived San Francisco intensity for Franciscan rocks for any given distance. By relating seismic shear-wave velocities to physical characteristics of geologic materials, Fumal (1978) has identified a series of seismically distinct units. For the unconsolidated to semiconsolidated sediments, he used texture and standard penetration resistance and depth to define six seismic units. For the bedrock materials, he used fracture spacing and hardness to define seven more seismic units. These 13 seismically distinct units and their intensity increments (provided by Fumal, 1978) are listed (table 2).

Table 2.-Predicted intensity increments for seismically distinct units

[Modified from Gibbs and others, 1985. Seismic units for bedrock are italicized; those for unconsolidated sediments are not]

\begin{tabular}{|c|c|c|c|c|c|}
\hline $\begin{array}{c}\text { Seismic } \\
\text { unit }\end{array}$ & & $\begin{array}{l}\text { Material } \\
\text { or rock type }\end{array}$ & $\begin{array}{l}\text { Properties } \\
\text { or hardness }\end{array}$ & $\begin{array}{l}\text { Fracture } \\
\text { spacing }\end{array}$ & $\begin{array}{c}\text { Predicted } \\
\text { San Francisco } \\
\text { intensity } \\
\text { increment }\end{array}$ \\
\hline \multicolumn{6}{|c|}{ Unconsolidated or semiconsolidated sediments } \\
\hline 1 & & Clay to silty clay & Very soft to soft & - & 2.9 \\
\hline II & & Clay to silty clay & Medium to hard & $\longrightarrow$ & 1.8 \\
\hline III & & Sand & Loose to dense & - & 1.7 \\
\hline IV & & Sandy clay-silt loam & $\begin{array}{l}\text { Interbedded coarse and } \\
\text { fine sediment }\end{array}$ & - & 1.4 \\
\hline v & & Sand & Dense to very dense & - & .9 \\
\hline VI & & Gravel & $\longrightarrow$ & - & .4 \\
\hline \multicolumn{6}{|c|}{ Bedrock } \\
\hline 1 & & Sandstone & Firm to soft & Moderate and wider & 0.7 \\
\hline II & . & lgneous, sedimentary & Hard to soft & Close to very close & .3 \\
\hline III & & Igneous, sandstone, shale & Hard to firm & Close & 0 \\
\hline IV & & lgneous, sandstone & Hard to firm & Close to moderate & -.3 \\
\hline V & & Sandstone, conglomerate & Firm to hard & Moderate to wider & -.5 \\
\hline VI & & Sandstone & Hard to quite firm & Moderate and wider & -.8 \\
\hline VII & & Igneous & Hard & Close to moderate & -1.1 \\
\hline
\end{tabular}


Table 3.-Average. predicted intensity increments for the geologic units in San Mateo County, Calif.

[Seismic units for bedrock are italicized; those for unconsolidated sediments are not. Geologic unit names and map-unit symbols may be modified from Brabb and Pampeyan (1983). Predicted intensity increments from J. F. Gibbs, T. E. Fumal, and R. D. Borcherdit (written commun., 1979-1982). Average intensity increments are accurate to plus or minus one-half increment]

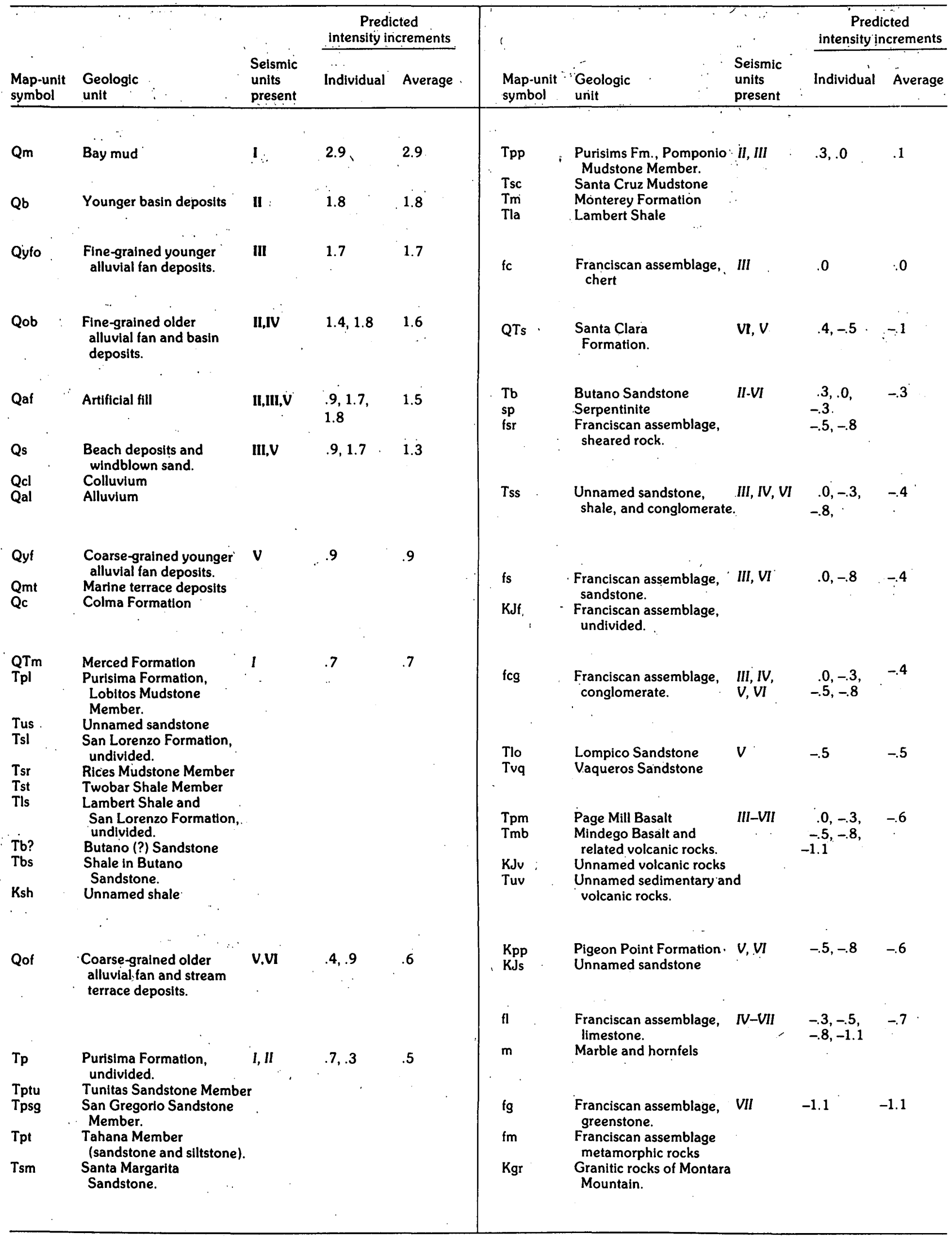


The problem then becomes one of correlating the seismic units with geologic units on existing geologic maps. The geologic units on the map of San Mateo County by Brabb and Pampeyan (1983) were used in this project, and the relations between the geologic and the seismic units have been provided by J.F. Gibbs, T.E. Fumal, and R.D. Borcherdt (written commun., 1979-1982) and are listed (table 3). Some geologic units contain materials with several physical properties and therefore encompass several seismically distinct units.

An average intensity increment for each of the geologic units was obtained by adding the intensity increments for all the seismically distinct units contained in each geologic unit and dividing by the number of those seismically distinct units. This averaging technique is obviously imprecise. If the exact percentage of each seismically distinct unit in each geologic unit were known, the average could be weighted accordingly. In addition, if the geologic units correspond more closely with the seismically distinct units, further refinements could be made in assigning intensity increments. The individual and average intensity increments are listed (table 3 ).

Correcting the attenuation formula for geology does not result in a completely accurate representation of intensity because other factors also affect intensity. For example, very deep alluvium probably has a minor effect on intensity. Insufficient data on other factors affecting intensity do not permit further refinement in the procedure at this time. Various degrees of saturation and the depth to the water table probably do not effect

Table 4.-Maximum distance from a fault to each intensity threshold for geologic units in San Mateo County, Calif.

[Geologic map-unit symbols from Brabb and Pampeyan (1983). See table 4 for equivalent mapunit names. Values of maximum distance in kilometers]

\begin{tabular}{lrrrrr}
\hline & \multicolumn{5}{c}{ San Francisco intensity } \\
\cline { 2 - 7 } Geologic map-unit symbol & A & \multicolumn{1}{c}{ B } & \multicolumn{1}{c}{ C } & \multicolumn{1}{c}{ D } & E \\
\hline Qm & 6.9 & 23 & 78 & 260 & 880 \\
Qb & 1.8 & 6.1 & 20 & 69 & 230 \\
Qyfo & 1.6 & 5.4 & 18 & 61 & 200 \\
Qob & 1.4 & 4.8 & 16 & 54 & 180 \\
Qaf & 1.3 & 4.2 & 14 & 48 & 160 \\
Qs, Qcl, Qal & 1.0 & 3.3 & 11 & 38 & 130 \\
Qyf, Qmt, Qc & .6 & 2.0 & 6.9 & 23 & 78 \\
QTm, Tpl, Tus, Tsl, Tsr, & & & & & \\
Tst, Tls, Tb?, Tbs, Ksh & .5 & 1.6 & 5.4 & 18 & 61 \\
Qof & .4 & 1.4 & 4.8 & 16 & 54 \\
Tp, Tptu, Tpsg, Tpt, Tsm & .3 & 1.3 & 4.2 & 14 & 48 \\
Tpp, Tsc, Tm, Tla & .2 & .8 & 2.6 & 8.8 & 29 \\
fc & .2 & .7 & 2.3 & 7.8 & 26 \\
QTs & .2 & .6 & 2.0 & 6.9 & 23 \\
Tb, sp, fsr & .1 & .5 & 1.6 & 5.4 & 18 \\
Tss, fs, fcg, KJf & .1 & .4 & 1.4 & 4.8 & 16 \\
Tlo, Tvq & .1 & .3 & 1.3 & 4.2 & 14 \\
Tpm, Tmb, KJv, Kpp, & & & & & \\
KJs, Tuv & .1 & .3 & 1.1 & 3.7 & 13 \\
fl, m & .1 & .3 & 1.0 & 3.3 & 11 \\
fg, fm, Kgr & .1 & .2 & .6 & 2.0 & 6.9 \\
& & & & & \\
\hline
\end{tabular}

Table 5.-Maximum distance from a fault to each intensity threshold for intensity increments

[Selected to illustrate uncertainty in distance calculations. Values of maximum distance in kilometers]

\begin{tabular}{lccccc}
\hline $\begin{array}{l}\text { Intensity } \\
\text { increment }\end{array}$ & \multicolumn{6}{c}{ San Francisco intensity } \\
\cline { 2 - 6 } & A & B & C & D & E \\
\hline. & & & & & \\
3.0 & 7.8 & 26 & 88 & 290 & 990 \\
2.9 & 6.9 & 23 & 78 & 260 & 880 \\
2.0 & 2.3 & 7.8 & 26 & 88 & 290 \\
1.9 & 2.0 & 6.9 & 23 & 78 & 260 \\
1.0 & .7 & 2.3 & 7.8 & 26 & 88 \\
.9 & .6 & 2.0 & 6.9 & 23 & 78 \\
.5 & .3 & 1.3 & 4.2 & 14 & 48 \\
.4 & .3 & 1.1 & 3.7 & 13 & 42 \\
0 & .2 & .7 & 2.3 & 7.8 & 26 \\
-.1 & .2 & .6 & 2.0 & 6.9 & 23 \\
-.5 & .1 & .3 & 1.3 & 4.2 & 14 \\
-.6 & .1 & .3 & 1.1 & 3.7 & 13 \\
-1.0 & .1 & .2 & .7 & 2.3 & 7.8 \\
-1.1 & .1 & .2 & .6 & 2.0 & 6.9 \\
\hline
\end{tabular}

intensity as significantly as do the geologic units in the bay area, however (J.F. Gibbs, T.E. Fumal, and R.D. Borcherdt, written commun., 1979).

\section{Calculating intensities on the basis of distance and geology}

By correcting the reference-bedrock attenuation formula with the average intensity increment for each geologic unit, one can predict the distance range from a fault trace for each intensity and each geologic unit. The maximum distances of these ranges are given (table 4) for an earthquake the same magnitude as the 1906 San Francisco earthquake.

The uncertainty of the intensity increments is as much as plus or minus one-half of an intensity increment, which is very high for large-distance calculations. The relation is illustrated in table 5. Distances (tables 4 and 5) are provided to two significant figures. This level of accuracy was chosen as a compromise between scientific knowledge and a need for geographic precision in drafting the resulting maps. Any user of these maps should realize these inherent limitations when dealing with individual locations. Soils and geologic information on that site would enable the user to assign each material to a single seismically distinct unit that has a more precise intensity increment. Individual calculations of distance could then yield more precise predictions of intensity.

\section{ESTIMATING DAMAGE ASSOCIATED WITH EACH INTENSITY}

\section{General observations}

Balancing the risk of earthquake losses against the cost of mitigation measures requires an estimate of the expected value of damage both in any particular earthquake and from several earthquakes during a longer period of time. Experience from past earthquakes can be used to estimate the damage that different types of buildings could experience when subjected to various intensities of ground shaking. This information and information on the recurrence time between earthquakes can be combined with that on the intensity maps. The resulting maps show the geographic distribution of the percentage (discounted to present value) of potential damage to different types of buildings from future earthquake ground shaking. 
Most surveys of earthquake damage have concentrated on areas of major damage and have neglected to identify areas where little or no damage occurred. Some statistics on minor damage have been collected in recent years, for example, from nuclear tests (Scholl, 1974b; Scholl and Farhoomand, 1973) and from moderate earthquakes in San Fernando (Scholl, 1974a; McClure, 1973) and Santa Rosa, Calif. (Steinbrugge and others, 1970). Although damage data have been collected after major earthquakes occurring outside the United States, these statistics are difficult to translate into possible damage in the United States because of the differences in construction.

\section{Damages for general building types}

Once detailed damage statistics are collected for particular earthquakes, the data need to be generalized to apply to future hypothetical events. This generalized data can be supplied as an approximate average cost factor for each intensity level. The cost factor is defined as the cost of repairing a building divided by the cost of replacing that building. it can be viewed as a percentage loss and is expressed in percentages. Page and others (1975) developed a table of approximate averagedamage cost factors for buildings in the United States (table 6). Grouping the damage data into cost factors for only two types of buildings is quite simplified. The following sections present attempts to refine the data.

Table 6.-Approximate damage cost factors for modern buildings

[From Page and others (1975)]

\begin{tabular}{lcc}
\hline $\begin{array}{l}\text { Modified } \\
\text { Mercalli }\end{array}$ & \multicolumn{2}{c}{ Damage cost factor (in percent) } \\
\cline { 2 - 3 } intensity & $\begin{array}{c}\text { Wood-frame } \\
\text { dwellings }\end{array}$ & $\begin{array}{c}\text { Other } \\
\text { buildings }\end{array}$ \\
\hline VI & $<0.2$ & $<1$ \\
VII & 2 & 5 \\
VIII & 5 & 15 \\
IX & 8 & 35 \\
X & 12 & $:>50$ \\
\hline
\end{tabular}

Refinements for damage to wood-frame dwellings

Algermissen, Steinbrugge, and their associates have made several refinements for damage data about woodframe dwellings. For example, Rinehart and others (1976) separated wood-frame dwellings into three categories of construction age: pre-1940, 1940-1949, and 1950 to present. In addition, their estimates of damage apply to three building components: finish, structure, and chimneys. These refinements of damage that are keyed to more building components (such as that used in earlier work by the U.S. Coast and Geodetic Survey, 1969; Steinbrugge and others, 1969; Algermissen and others, 1969) are not of great significance to this project. The equivalent to the average damage cost factor of Page and others (1975) can be derived from the work of Rinehart and others (1976) by multiplying their damage factors (incidence of each type of damage) by their damage ratios (fraction of value lost for each type of damage) and summing these products for finish, structural, and chimney damage. The resulting values, for wood-frame dwellings built since 1950, are presented (table 7). These composite damage cost factors are larger than the average cost factors of Page and others (1975). The factors for older buildings are even larger and values vary (table 8 ) with age of construction.
Table 7.-Approximate damage cost factors for wood-frame dwellings built since 1950 , by building component

[From Rinehart and others (1976); data from Page and others (1975) included for comparison with the "Total" column]

\begin{tabular}{lccccc}
\hline Modified & \multicolumn{3}{c}{ Damage cost factor (in percent) for wood-frame dwellings } \\
\cline { 2 - 6 } $\begin{array}{l}\text { Mercalli } \\
\text { Intensity }\end{array}$ & $\begin{array}{c}\text { Finish } \\
\text { components }\end{array}$ & $\begin{array}{c}\text { Structural } \\
\text { components }\end{array}$ & $\begin{array}{c}\text { Chimneys' } \\
\text { coge and } \\
\text { others }\end{array}$ \\
\hline IV & 0 & 0.10 & 0 & 0.10 & 0 \\
V & 0 & 0.25 & 0 & 0.25 & 0 \\
VI & 0 & 2.11 & 0 & 2.11 & $<0.2$ \\
VII & 0.03 & 4.44 & 0.07 & 4.54 & 2 \\
VIII & 0.60 & 6.28 & 0.18 & 7.06 & 5 \\
IX & 1.62 & 8.50 & 0.30 & 10.42 & 8 \\
X & -2 & -2 & -2 & $14.00^{2}$ & 12 \\
\hline
\end{tabular}

'Factor is multiplied by the percentage of homes assumed to have chimneys, in this case 25 percent.

${ }^{2}$ Total factor obtained by extrapolation. Factor for components not extrapolated.

Refinements for damage to other buildings

Further refinements of damage estimates for other types of buildings become even more complex. Algermissen and Steinbrugge avoided these buildings when making the damage estimates for the U.S. Coast and Geodetic Survey (1969). However, in a recent article (1978) they made such estimates for several classes of buildings. The classes of buildings they considered are shown (table 9), and the percentage of losses (damage cost factors) to general types of buildings for modified Mercalli intensities are shown (fig. 3).

Table 8.-Approximate damage cost factors for woodframe dwellings of various ages [From Rinehart and others, 1976]

\begin{tabular}{|c|c|c|c|c|c|}
\hline \multirow{3}{*}{$\begin{array}{l}\text { Modified } \\
\text { Mercalli } \\
\text { intensity }\end{array}$} & \multicolumn{5}{|c|}{ Damage cost factor (in percent) for wood-frame dwellings } \\
\hline & Built & Percent & Built from & Percent & Built prior \\
\hline & 1950-present & change' & $1940-1949$ & change ${ }^{1}$ & to 1940 \\
\hline IV & 0.10 & 0 & 0.1 & 0 & 0.10 \\
\hline V & 0.25 & 0 & 0.25 & 0 & 0.25 \\
\hline VI & 2.11 & 1 & 2.14 & 79 & 3.76 \\
\hline VII & 4.54 & 17 & 5.34 & 58 & 7.20 \\
\hline VIII & 7.06 & 8 & 7.66 & 47 & 10.44 \\
\hline IX & 10.42 & 9 & 11.42 & 51 & 15.74 \\
\hline
\end{tabular}

'Percentage increase (to nearest percent) from cost factor for "Built 1950-present" provided in these two columns.

\section{Damage information used in this project}

Comparison of tables 6,7 , and 8 , shows that development of damage cost factors by earthquakeintensity level is an inexact science. The descrepancies are partly the result of limited data points and partly the result of the imprecise and subjective nature of the intensity scale. More research is needed. Average damage cost factors (percentage of loss) of Rinehart and others (1976) were used in producing the damagepotential map of wood-frame dwellings (sheet 1). Cost factors for buildings in the group of classes 3B, 3D, 4C, and $5 \mathrm{C}$ (most concrete and steel buildings) and class 4D 
Table 9.-Building classification

[From Algermissen and Steinbrugge, 1978]

Notation used in loss tables
Brief description of subclasses of five, broad, building classes
$1 \mathrm{~A}$

$1 B$

$2 A$

$2 B$

3LA

3LB

3LC

3LD

3HA, 3HB,

3HC, $3 \mathrm{HD}$

4LA

4LB

$4 L C$

4LD

4LE

4HA, 4HB,

$4 \mathrm{HC}, 4 \mathrm{HD}, 4 \mathrm{HE}$

$5 A$

$5 B$

5C

5D

$5 \mathrm{E}$

$5 \mathrm{~F}$
Wood-frame and frame-stucco dwellings

Wood-frame and frame-stucco buildings not qualifying under 1A (usually large-area nonhabitational units); not considered in this study.

One story, all metal; floor area less than $20,000 \mathrm{ft}^{2}$.

All metal buildings not considered under $2 \mathrm{~A}$.

Steel frame; superior damage-control features; less than four stories.

Steel frame; ordinary damage-control features; less than four stories.

Steel frame; intermediate damage-control features (between 3LA and 3LB); less than four stories.

Floors and roofs not concrete; less than four stories.

Descriptions are the same as for 3LA, 3LB, 3LC, and 3LD except that buildings have four or more stories.

Reinforced concrete; superior damage-control features; less than four stories.

Reinforced concrete; ordinary damage-control features; less than four stories.

Reinforced concrete; intermediate damage-control features (between 4LA and 4LB) less than four stories.

Precast reinforced concrete, lift slab, less than four stories.

Floors and roofs not concrete, less than four stories.

Descriptions are the same as for 4LA, 4LB, 4LC, 4LD, and 4LE except that buildings have four or more stories.

Dwellings, not over two stories in height, constructed of (a) poured-in-place reinforced concrete, with roofs and second floors of wood frame or (b) adequately reinforced brick or hollow-concrete block masonry, with roofs and floors of wood; not considered in this study.

One-story buildings have superior earthquake damage-control features, including exterior walls of (a) poured-in-place reinforced, and (or) (b) precast reinforced concrete, and (or) (c) reinforced brick masonry or reinforced-concrete brick masonry, and (or) reinforced hollow-concrete block masonry. Roofs and supported floors are of wood or metal-diaphram assemblies. Interior bearing walls are of wood frame or any one, or a combination, of the aforementioned wall materials.

One-story buildings having construction materials listed for Class $5 \mathrm{~B}$, but with ordinary earthquake damage-control features.

Buildings having reinfored concrete load-bearing walls and floors and roofs or wood, but not qualifying for Class $4 \mathrm{E}$; and buildings of any height having Class $5 \mathrm{~B}$ materials of construction including wall reinforcement; also included are buildings with roofs and supported floors of reinforced concrete (precast or otherwise) not qualifying for Class 4.

Buildings having unreinforced solid-unit masonry of unreinforced brick, unreinforced concrete brick, unreinforced stone, or unreinforced concrete, where the loads are carries in whole or in whole or in part by the walls and partitions. Interior partitions may be wood frame or any of the aforementioned materials. Roofs and floors may be of any material. Not qualifying are buildings having nonreinforced load walls of hollow tile or other hollow-unit-masonry, adobe, or cavity construction.

Buildings having load-carrying walls of hollow tile or other hollow-unit-masonry construction, adobe, and cavity-wall construction, and any building not covered by any other class; not considered in this study. 


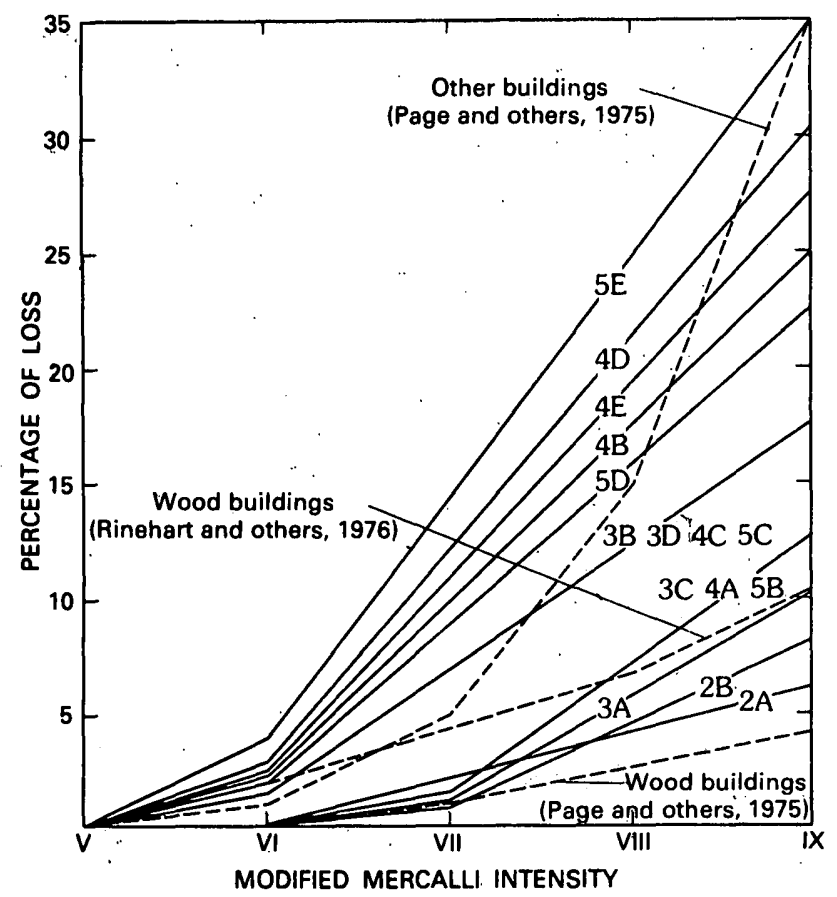

Figure 3.-Relation of modified Mercalli intensity to percentage of loss (damage cost factor) by class of construction (from Alqermissen and Steinbrugge, 1978) Descriptions of the various classes (1 through 5) are in table 9. High- and low-rise subclasses of classes 3 and 4 have been combined. The percentage of loss for wood frame dwellings (from Rinehart and others, 1976; Page and others, 1975), and for other buildings (as developed by Page and others, 1975), are shown by dashed lines and are included for comparison.

(ordinary tilt-up concrete buildings) from Algermissen and Steinbrugge (1978) were used to produce sheets 2 and 3 , respectively. These three building groups were selected to indicate the differences in cumulative damage-potential maps that can be attributed to various types of construction. In all cases, the values have been extraolated and converted to San Francisco intensity (table 10).

Table 10.-Damage cost factors for buildings affected by selected intensities

\begin{tabular}{|c|c|c|c|c|}
\hline \multirow[b]{2}{*}{$\begin{array}{l}\text { Modified } \\
\text { Mercalli } \\
\text { intensity }\end{array}$} & \multirow[b]{2}{*}{$\begin{array}{l}\text { Estimated } \\
\text { San } \\
\text { Francisco } \\
\text { intensity }\end{array}$} & \multicolumn{3}{|c|}{ Damage cost factor (in percent) } \\
\hline & & $\begin{array}{l}\text { Wood- } \\
\text { frame } \\
\text { dwellings } \\
\text { (class 1A) }\end{array}$ & $\begin{array}{l}\text { Ordinary concrete-block } \\
\text { and steel-frame buildings } \\
\text { and some reinforced } \\
\text { concrete buildings } \\
\text { (classes } 3 \mathrm{~B}, 3 \mathrm{D}, 4 \mathrm{C}, 5 \mathrm{C} \text { ) }\end{array}$ & $\begin{array}{l}\text { Ordinary } \\
\text { tilt-up } \\
\text { concrete } \\
\text { buildings } \\
\text { (class 4D) }\end{array}$ \\
\hline VI & E & 2 & 1.5 & 4 \\
\hline VII & $D$ & 5 & 7 & 12 \\
\hline VIII & $\mathrm{C}$ & 7 & 12 & 21 \\
\hline$x$ & B & $14^{\prime}$ & $22^{\prime}$ & $35^{1}$ \\
\hline XI-XII & A & $14^{\prime}$ & $22^{\prime}$ & $35^{\prime}$ \\
\hline
\end{tabular}

Values obtained by extrapolation; estimates are probably low.

\section{ESTIMATING FAULT ACTIVITY}

To produce maps of the expected value of potential damage from earthquakes originating on any fault in the region, information is needed about the recurrence intervals for earthquakes of various magnitudes for each fault. Given a constant slip rate (the rate at which one side of a fault moves relative to the other), the recurrence of a given magnitude event can be calculated by using this formula (from Slemmons, 1977):

$$
R I=\frac{10^{x}}{S}, \text { where } x=\frac{M-6.717}{1.214}
$$

where $R I$ is the recurrence interval in years, $S$ is the slip rate in meters per year, and $M$ is the magnitude, which assumes that all earthquakes are of a single specified magnitude. However, the distribution of large and small events on each fault and the amount of slip occurring through aseismic creep also affect the cumulativedamage estimates. The annual cost factor for damage to buildings near a fault is hypothetically much greater for moderate events (magnitude 5.3 to 6) than for lower or higher magnitude events (table 11). To avoid making

Table 11.-Annualized cost factors of earthquake damage to wood-frame dwellings near a fault with a series of earthquakes of the listed magnitude and a slip rate of 0.75 $\mathrm{cm} / \mathrm{yr}$

[Recurrence interval was calculated by Slemmons' (1977) formula. Maximum intensity was calculated by a formula also used by Algerissen and Steinbrugge (1978). Annualized cost factor is doubled if slip rate is $1.5 \mathrm{~cm} / \mathrm{yr}$; it is reduced $1 / 3$ if $1 / 3$ of the slip rate is released as creep. The following average percentages are assumed for each intensity: VI, 0.1; VII, 5; IX, 8; and X, 12 (Page and others, 1975); and XI-XII, 20]

\begin{tabular}{ccccc}
\hline $\begin{array}{c}\text { Magnitude } \\
\text { (Richter) }\end{array}$ & $\begin{array}{c}\text { Recurrence } \\
\text { interval (yr) }\end{array}$ & $\begin{array}{c}\text { Maximum } \\
\text { intensity }\end{array}$ & $\begin{array}{c}\text { Percentage of } \\
\text { damage for maximum } \\
\text { intensity }\end{array}$ & $\begin{array}{c}\text { Annualized } \\
\text { cost factor } \\
\text { (in percent) }\end{array}$ \\
\hline$<5$ & $<5$ & $<6 / \mathrm{NI}$ & 0 & 0 \\
5.0 & 5 & $6.0 / \mathrm{NI}$ & .1 & .016 \\
5.3 & 9 & $6.45 / \mathrm{NI}$ & .5 & .056 \\
5.5 & 13 & $6.75 / \mathrm{NI}$ & 1.2 & .091 \\
5.6 & 16 & $6.90 / \mathrm{NII}$ & 1.6 & .100 \\
5.7 & 19 & $7.05 / \mathrm{VII}$ & 2.0 & .105 \\
5.8 & 23 & $7.2 / \mathrm{NII}$ & 2.3 & .100 \\
5.9 & 28 & $7.35 / \mathrm{NII}$ & 2.5 & .089 \\
6.0 & 34 & $7.5 / \mathrm{NIII}$ & 3.1 & .091 \\
6.2 & 50 & $7.8 \mathrm{NIII}$ & 4.2 & .084 \\
6.5 & 88 & $8.25 / \mathrm{VIII}$ & 5.7 & .065 \\
6.7 & 129 & $8.55 / \mathrm{IX}$ & 6.4 & .050 \\
6.9 & 189 & $8.85 / \mathrm{IX}$ & 7.6 & .040 \\
7.1 & 276 & $9.15 / \mathrm{IX}$ & 8.8 & .032 \\
7.3 & 403 & $9.45 / \mathrm{IX}$ & 9.5 & .022 \\
8.0 & 1.520 & $10.5 / \mathrm{XI}$ & 15 & .010 \\
\hline
\end{tabular}

estimates of the number of large and small earthquakes, some researchers (for example, Algermissen and Steinbrugge, 1978) have used the historic record of movement, which now approaches 200 years in California. The usefulness of this procedure is debatable given the size of recurrence intervals (table 12). 
A more direct way to avoid this problem is to use slip rate as the critical measure of seismicity. Relatively speaking, a fault with a slip rate of $1.5 \mathrm{~cm} / \mathrm{yr}$ would cause about twice as much damage to nearby homes than one with a slip rate of $0.75 \mathrm{~cm} / \mathrm{yr}$ if the faults have earthquakes of similar maximum magnitude and similar distributions of large and small events.

To graphically depict the uncertainties introduced by these different assumptions, two test maps (fig. 4) that display cumulative damage potential for small woodframe dwellings have been produced using the data of Page and others (1975). The damage potential if the slip occurs during a small number of events is shown (fig. 4A) and the maximum magnitude is calculated using one-half the fault length. Figure $4 B$ uses the unrealistic assumption that the slip occurs entirely during a large number of magnitude- 5.5 events (with a maximum San Francisco intensity of D). The slip rates used in the analysis are given (table 12). The maximum magnitudes used to calculate the recurrence intervals in table 12 are those in table 1.

The recurrence intervals calculated (table 12) by using Slemmons' (1977) formula are for individual points along the faults. They are not synonymous with the number of earthquakes anticipated in the bay area, because fault rupture length is not included in the formula. For example, the entire San Andreas fault zone in the bay area could have two magnitude-8.4 events having ruptures $600 \mathrm{~km}$ long in 1,000 years or tens of thousands of magnitude-5.5 events with ruptures $4.5 \mathrm{~km}$ long in 1,000 years.
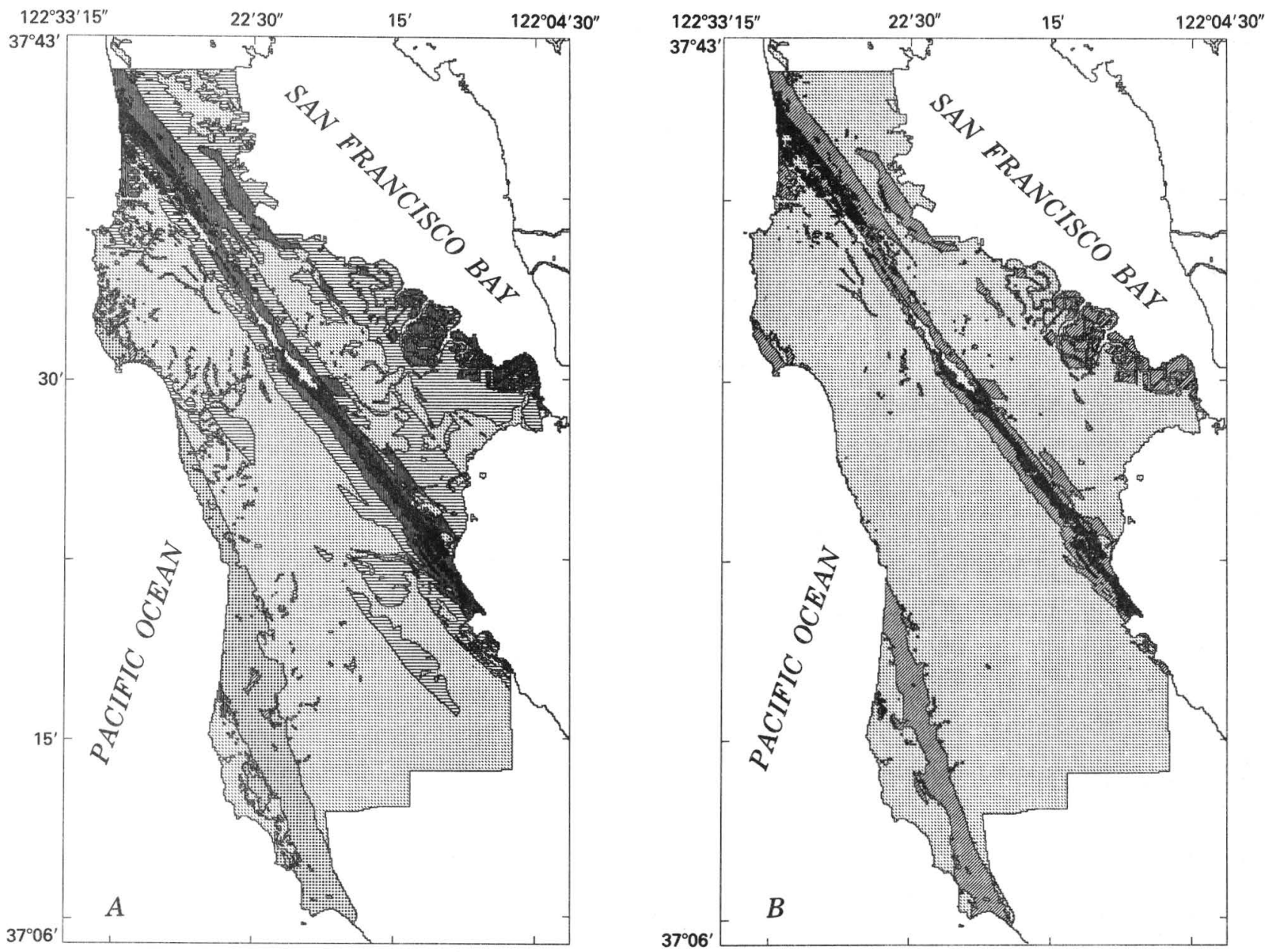

$\begin{array}{llllllll}0 & 2 & 4 & 8 & 12 & 16 & 20 & \text { KILOMETERS }\end{array}$

Figure 4.-Comparison of cumulative damage potential to wood-frame dwellings in San Mateo County, Calif., using different distributions of large and small earthquakes. The percentage of damage is based on statistical procedures using data on recurrence intervals for magnitude-5.5 earthquakes and average building damage for wood-frame dwellings (Page and others, 1975). Patterns indicate gradational values of cumulative damage potential from moderate (darkest) to very low (lightest). A, Damage potential if slip occurs during a small number of earthquakes with relatively large magnitude. $B$, Damage potential if slip occurs during a large number of magnitude5.5 earthquakes. 
Table 12.-Relative activity and recurrence intervals for major earthquakes at any point on the principal active and potentially active faults in the San Francisco Bay area, California

(N/A not applicable; slip rate assumed very low (equal to or less than $0.1 \mathrm{~cm} / \mathrm{yr}$ ) in all cases, yielding recurrence intervals of thousands of years for even moderate earthquakes. One major problem with using a calculated recurrence interval based on slip rate is that the interval for large magnitude earthquakes on long faults, such as the San Andreas and Calaveras, becomes too large to agree with historic data. To lessen this problem, the recurrence intervals used for these two long faults are those for the shorter faults segments]

\begin{tabular}{|c|c|c|c|c|}
\hline \multirow{3}{*}{ Fault } & \multirow{3}{*}{$\begin{array}{l}\text { Long-term } \\
\text { slip rate }(\mathrm{cm} / \mathrm{yr}) \\
\text { (Herd. 1978a) }\end{array}$} & \multicolumn{3}{|c|}{ Recurrence interval' $\left(\mathrm{yr}^{2}\right)$} \\
\hline & & \multicolumn{2}{|c|}{$\begin{array}{c}\begin{array}{c}\text { For maximum } \\
\text { event }\end{array} \\
\end{array}$} & \multirow{2}{*}{$\begin{array}{c}\text { Magnitude-5.5 } \\
\text { event }\end{array}$} \\
\hline & & $1 / 2 \mathrm{~L}$ & $1 \mathrm{~L}$ & \\
\hline $\begin{array}{l}\text { San Andreas } \\
\text { Holister-Bolinas } \\
\text { Bolinas-Cape Mendocino }\end{array}$ & $\begin{array}{l}2.5 \text { (ave.) } \\
2.0 \\
3.0\end{array}$ & $\begin{array}{r}1.000 \\
100 \\
100\end{array}$ & $\begin{array}{r}2.000 \\
300 \\
300\end{array}$ & $\begin{array}{l}4 \\
5 \\
3\end{array}$ \\
\hline $\begin{array}{l}\text { Calaveras } \\
\text { Calaveras-Paicines } \\
\text { Calaveras-Sunol }\end{array}$ & $\begin{array}{l}1.0 \text { (ave.) } \\
1.5 \\
.75\end{array}$ & $\begin{array}{l}300 \\
100 \\
100\end{array}$ & $\begin{array}{l}600 \\
200 \\
300\end{array}$ & $\begin{array}{r}10 \\
7 \\
10\end{array}$ \\
\hline Pleasanton & N/A & - & - & \\
\hline Concord/Green Valley & .75 & 200 & 500 & 10 \\
\hline Antioch & $N / A$ & - & - & - \\
\hline Hayward (incl. Crosley) & .75 & 200 & 400 & 10 \\
\hline Healdsburg/Rodgers Creek & .75 & 200 & 300 & 10 \\
\hline Maacama & .75 & 300 & 600 & 10 \\
\hline San Gregorlo & 1.0 & 200 & 400 & 10 \\
\hline Verona & $N / A$ & - & - & - \\
\hline Sllver Creek & N/A & - & - & - \\
\hline Evergreen & N/A & - & - & - \\
\hline Dunnigan Hills & N/A & - & - & - \\
\hline West Napa & $N / A$ & - & - & - \\
\hline Cordella & N/A & - & - & - \\
\hline Sargent (south of $-37^{\prime \prime} 1$ lat.) & $0.3^{3}$ & 70 & 150 & 30 \\
\hline Sargent (north of $37^{\prime \prime}$ lat.) & $N / A$ & - & - & - \\
\hline Las Positas & N/A & - & - & - \\
\hline Greenville & N/A & - & - & - \\
\hline Faults near Trenton & $N / A$ & - & - & - \\
\hline Tolay & $N / A$ & - & - & - \\
\hline $\begin{array}{l}\text { Faults east of Bennelt } \\
\text { Valley and Santa Rosa }\end{array}$ & N/A & - & - & - \\
\hline Zayante & $N / A$ & - & - & - \\
\hline Berrocal & $N / A$ & - & - & - \\
\hline Midway & $N / A$ & - & - & - \\
\hline San Joaquin & $02^{4}$ & 20.000 & 40.000 & 500 \\
\hline Monte Vista & $N / A$ & & & - \\
\hline Coyote Creek & $N / A$ & - & - & - \\
\hline Piercy & $N / A$ & - & - & - \\
\hline Serra & N/A & - & - & - \\
\hline Ortigalita & .001 & 40.000 & 80.000 & 1.000 \\
\hline
\end{tabular}

'For a point on the fault.

${ }^{2}$ Years from Slemmons' (1977) formula rouded to one stgnificant fiqure.

'Prescott and Burford. 1976

'Prescott and Burford. 1976.

Litenkaemper, written commun.. 1983. 
ADDITIONAL FAULT INFORMATION

\begin{tabular}{|c|c|c|c|c|c|c|c|c|c|}
\hline & \multicolumn{2}{|c|}{$\begin{array}{l}\text { Published length }(\mathrm{km}) \\
\text { Length used here }(\mathrm{L})\end{array}$} & \multicolumn{4}{|c|}{ Included in compilation } & \multicolumn{3}{|c|}{$\begin{array}{l}\text { Published age of displacement }{ }^{1} \\
\text { Age of displacement used here (A) }\end{array}$} \\
\hline & $\begin{array}{c}\text { Wesson } \\
\text { and others } \\
(1975)\end{array}$ & $\begin{array}{l}\text { Herd, Helley } \\
(1977-1986) \\
\text { [source noted }^{2}\end{array}$ & $\begin{array}{c}\text { Calif. Div. } \\
\text { Mines and } \\
\text { Geology } \\
(1974-1983)\end{array}$ & $\begin{array}{c}\text { Jennings } \\
(1975)\end{array}$ & $\begin{array}{l}\text { Wesson } \\
\& \text { others } \\
(1975)\end{array}$ & $\begin{array}{c}\text { Herd, Helley } \\
(1977-1986) \\
\text { [source noted] }^{2}\end{array}$ & $\begin{array}{l}\text { Jennings, } \\
\text { (1975) }\end{array}$ & $\begin{array}{l}\text { Wesson and } \\
\text { others } \\
(1975)\end{array}$ & $\begin{array}{c}\text { Herd, Helley } \\
(1977-1986) \\
\text { [source noted }^{2}\end{array}$ \\
\hline San Andreas & $1,200(\mathrm{~L})$ & - & Yes & Yes & Yes & Yes[6] & Historic & Historic & Historic[6](A) \\
\hline Hollister-Bolinas & - & $160[6](L)$ & Yes & Yes & Yes & Yes[6] & Historic & Historic & Historic[6](A) \\
\hline Bolinas-Cape Mendocino & - & $270[6](L)$ & Yes & Yes & Yes & Yes[6] & Historic & Historic & Historic[6](A) \\
\hline Calaveras & 115 & $170[6](\mathrm{L})$ & Yes & Yes & Yes & Yes[6] & Historic & Historic & Historic[6](A) \\
\hline Calaveras-Paicines & - & $100[6](\mathrm{L})$ & Yes & Yes & Yes & Yes[6] & Historic & Historic & Historic $[6](A)$ \\
\hline Calaveras-Sunol & - & $70[6](\mathrm{L})$ & Yes & Yes & Yes & Yes[6] & Historic & Historic & Historic[6](A) \\
\hline Pleasanton & $9(\mathrm{~L})$ & - & Yes & Yes & Yes & Yes[7] & Quaternary & Historic $^{3}$ & Historic[7](A) \\
\hline Concord/Green Valley & 56 & $20+90[6](L)$ & Yes & Yes[2] & Yes & $\mathrm{No}^{4}$ & Quaternary & Historic & Historic[6](A) \\
\hline Antioch & $37(\mathrm{~L})$ & $12[4]$ & Yes & Yes & Yes & Yes[4] & Historic & Historic & Historic[4](A) \\
\hline Hayward (incl. Crosley) & 72 & $90[6](\mathrm{L})$ & Yes & Yes & Yes & Yes[4] & Historic & Historic & Historic[6](A) \\
\hline Healdsburg/Rodgers Creek & $72(\mathrm{~L})$ & - & Yes & Yes & Yes & No & Quaternary & Historic(A) & - \\
\hline Maacama & 35 & $140[6](L)$ & Yes & Yes & Yes & Yes[4] & Quaternary & Holocene & Historic[6](A) \\
\hline San Gregorio & 200 & $140[6](L)$ & Yes & Yes & Yes & Yes[6] & Quaternary & Holocene & Holocene[8](A) \\
\hline Verona & - & $10[5](\mathrm{L})$ & No & Yes & Yes & Yes[5] & Quaternary & Quaternary & Holocene[8](A) \\
\hline Silver Creek & 20 & $30[14](L)$ & Yes & Yes & Yes & No & Quaternary & Historic(A) & - \\
\hline Evergreen & - & $14[14](L)$ & Yes & Yes & Yes & No & Quaternary & Historic(A) & - \\
\hline Dunnigan Hills & - & $10[4](L)$ & No & Yes & No & Yes[4] & Quaternary & - & Holocene[4](A) \\
\hline West Napa & 17 & $28[4](L)$ & No & Yes & Yes & Yes[4] & Quaternary & Holocene & Holocene[4](A) \\
\hline Cordelia & - & $19[4](\mathrm{L})$ & No & No & No & Yes[4] & - & - & Holocene[4](A) \\
\hline Sargent (north of $-37^{\circ}$ lat.) & 55 & $20[14](L)$ & Yes & Yes & Yes & Yes[6] & Quaternary & Holocene & Historic[13](A) \\
\hline Sargent (south of $-37^{\circ}$ lat.) ) & & $17[14](\mathrm{L})$ & Yes & Yes & Yes & Yes[6] & Quaternary & Holocene & Historic $[13](A)$ \\
\hline Las Positas & - & $14[5](\mathrm{L})$ & No & Yes & Yes & Yes[5] & Quaternary & Quaternary & Quaternary[8](A) \\
\hline Greenville & - & $50[1](\mathrm{L})$ & Yes & Yes & Yes & Yes[5] & Historic & Quaternary & Historic[9](A) \\
\hline Faults near Trenton & $27(L)$ & $9[11]$ & No & Yes & Yes & Yes[11] & Quaternary & Quaternary & Pleistocene $[11](\mathrm{A})$ \\
\hline
\end{tabular}




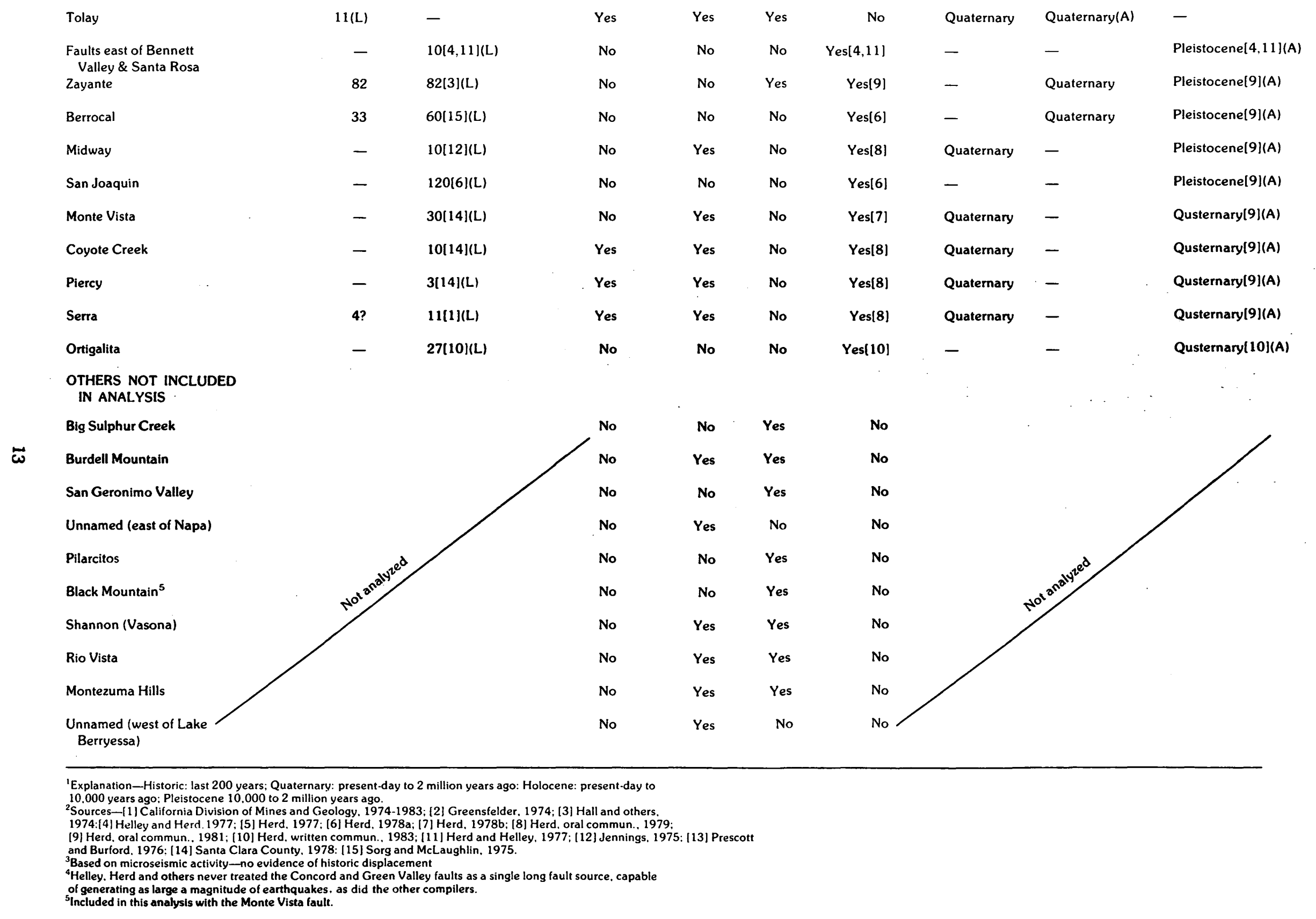


The two test maps (fig. 4) are remarkably similar, considering that they were produced to illustrate the upper and lower extremes of the possible damage that might occur. The overall damage patterns are parallel, although the damages near the fault are greater when assuming the large number of magnitude- 5.5 events, and the damages at large distances from faults are greater when assuming that only a few, very large earthquakes occur. Neither test map is a precise picture of reality. However, the map based on large earthquakes (fig. $4 A$ ) is considered to be a closer estimate of reality.

\section{COMBINING DAMAGE INFORMATION FOR SEVERAL EVENTS}

Discount rates and present values must be used to more fully assess the cost of future rare events. "Discounting" may be defined as the act of reducing the value of some future dollar amount to its present value by a given amount to cover interest-the reverse of what happens in an interest-bearing savings account. In this case, the value of the account is known at some future time, and the calculated value is an estimate of what must be in that account now to provide the future value. The expected value of all future costs (losses), discounted to the present, is chosen as a way to compare losses that could occur at different times in the future. Obviously, losses that would occur as the result of another 1906 San Francisco earthquake 3 hours from now are more important to us than those that would occur in such an earthquake 100 years from now. Actually one doesn't know when in the next 100 years such an earthquake will occur, and it is equally likely to occur in any year during that time. Discounting these losses to their present value enables one to compare three cases: (a) an earthquake occurs in 3 hours, (b) an earthquake occurs sometime in the next 100 years, and (c) an earthquake occurs in exactly : 100 years (This concept is illustrated in figure 5 ).
To calculate the total expected percentage loss for all future earthquakes, the damage cost factors from table 10 are divided by the recurrence intervals of various events from table 12. Next, the percentages must be discounted to obtain their present value. If a discount rate of $\mathbf{1 0}$ percent is used, a rate commonly used in cost-benefit analyses, and if the term over which the percentages are discounted is assumed to be forever, the present values of those percentage losses can be estimated by dividing the amounts calculated above by the discount rate $(0.10)$. If 50 percent damage is assumed to occur, the present value of damage to a $\$ 100,000$ house would be $\$ 50,000, \$ 5,000$, and almost nothing for the three cases, respectively. (See Laird and others, 1979, p. 6-9).

\section{MAPPING EARTHQUAKE INTENSITY AND} CUMULATIVE DAMAGE POTENTIAL

By using the information on faults, attenuation, geology, and potential damage provided in this report, it is possible to create intensity maps for earthquakes on individual faults and then to combine those maps in two different ways:

1. By taking the highest intensity at a location from any of the maps, create a new map showing the maximum intensity for all possible fault sources, or

2. By weighting the intensity maps for individual faults, using recurrence intervals and damage data, create maps of the percentage of cumulative damage potential (discounted to present value).

Other maximum-intensity maps are available (see Borcherdt and others, 1975), so only the second type of map has been produced here. Because damages vary by type of construction, maps of expected cumulative damage potential have been produced for three different building types: wood-frame dwellings (sheet 1), ordinary concrete-block and steel-frame buildings

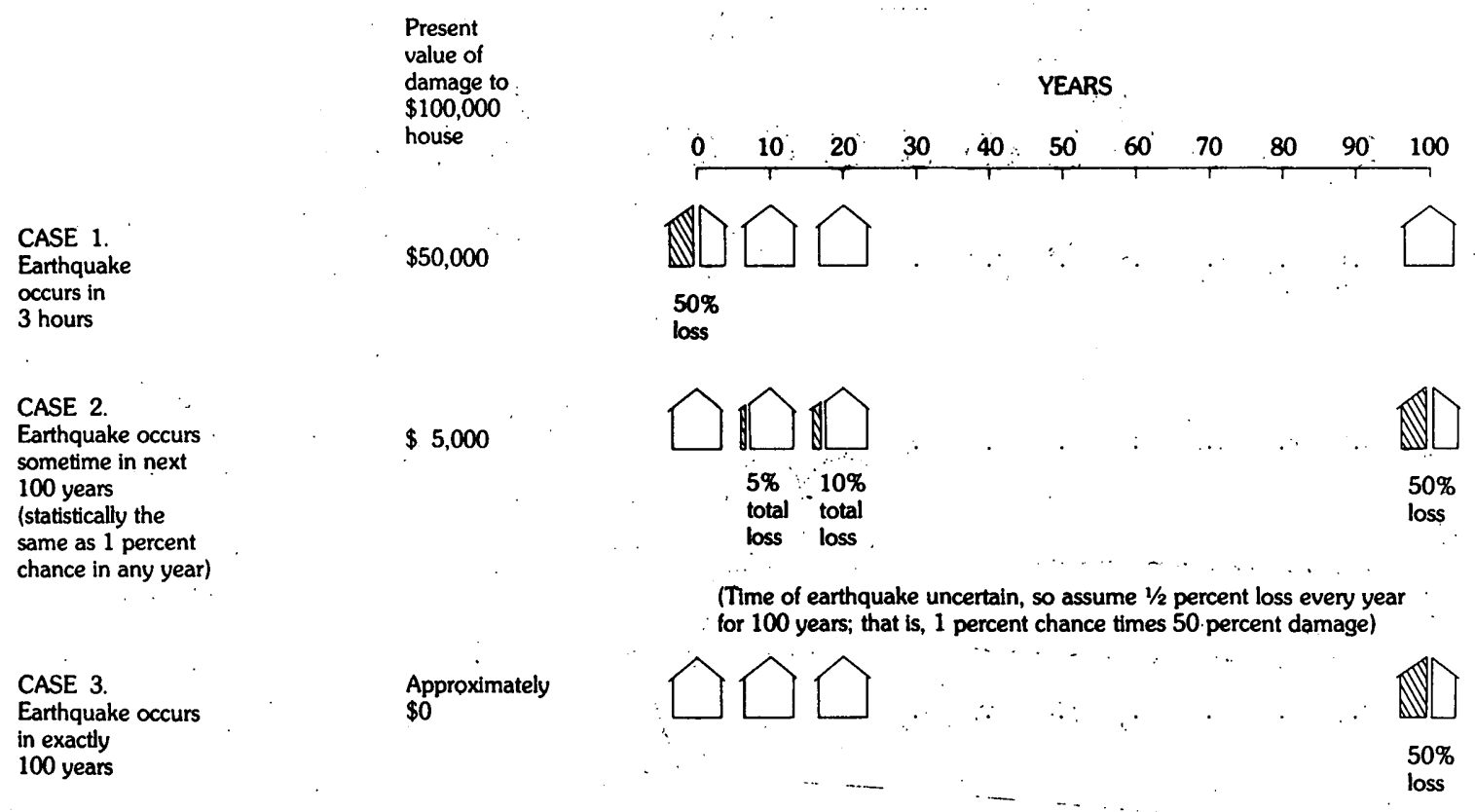

Figure 5.-Present value of damage for selected hypothetical cases. 
and some reinforced-concrete buildings (sheet 2), and ordinary tilt-up concrete buildings (sheet 3 ). The colors for the percentage ranges of cumulative damage are the same on all three plates to best illustrate the effects on different building types.

\section{ASSESSING PROPERTY AND POPULATION AT RISK}

The three maps of cumulative damage potential do not use any information on the location of specific buildings. They are meant to indicate only the percentage of potential loss inherent in a particular geographic location if specific types of buildings are located there. By comparing the damage potential maps to political boundaries (such as counties or cities), or to mapped units for which socioeconomic data are available (such as land use or census tracts), it is possible to develop general information about the hazard to property and people. The maps should not be used to determine engineering design or potential earthquake damage at a specific site. However, they can be used in making general land-use decisions and in defining general areas where additional structural- or subdivision-design precautions are potentially worthwhile. For example, in areas of high risk the most earthquake-resistant types of buildings (wood-frame) might be suitable, and in such areas particular attention should be directed toward design of utilities and access or egress.

1980 census-tract boundaries have been entered into ABAG'S computer-mapping system. County boundaries have been obtained by aggregating census tracts. The city boundaries used on the maps are those of city spheres-of-influence, assigned by San Mateo County's Local Agency Formation Commission (LAFCO) current as of 1975; they are not the legal boundaries of the cities, for these boundaries change with each new annexation. Land-use information was obtained from a series of land-use and land-cover maps showing four levels of land-use categories (U.S. Geological Survey, 1978).

Tables 1 and 2 of sheets 1,2 , and 3 show the amount of land by jurisdiction and by land-use type in each of the categories on three damage potential maps (sheets $1-3)$. The tables of damage potential by jurisdiction emphasize the relative vulnerability of land located in Burlingame, Daly City, Menlo Park, Millbrae, Pacifica, Portola Valley, Redwood City, San Bruno, So. San Francisco, and Woodside as compared with Atherton, Belmont, Brisbane, Colma, Hillsborough, and San Carlos. Such jurisdictional data become even more useful when available for the entire nine-county bay area. For example, the data enable comparisons between alternate jurisdictional locations for future regional growth and intensified development. The tables of damage potential by land use enable other interesting observations. For example, land areas used for heavy industry, which would be more likely to have concrete and steel or tilt-up concrete buildings than wood-frame buildings, are typically in areas with a relatively high percentage of cumulative damage potential, often higher than 6 percent for tilt-up buildings. Similarly, highway and power-transmission facilities are located in areas with relatively high percentages of cumulative damage potential in the county. On the other hand, residential developments, typically wood-frame buildings, are in areas with relatively low damage potential, usually less than 2 percent.

To determine how individual properties are affected, more detailed data on type, age, and value of existing buildings must be obtained. This process has been used by Algermissen and Steinbrugge (1978) to estimate damage for various hypothetical earthquakes and past earthquake events. The damage-potential maps (sheets $1-3$ ) are more geographically detailed than earlier maps and therefore are more useful for land-use decisions.

\section{REFERENCES CITED}

Algermissen, S.T., and Steinbrugge, K.V., 1978, Earthquake losses to buildings in the San Francisco Bay area, in Proceedings of the Second International Conference on Microzonation for Safer Construction-Research and Application, San Francisco, Calif., 1978: v. 1, p. 291-302.

Algermissen, S.T., and Stepp, J.C., Rinehart, W.A., and Arnold, E.P. 1969, Studies in seismicity and earthquake damage statistics, 1969, Appendix B: U.S. Coast and Geodetic Survey, 68 p.

Borcherdt, R.D., Gibbs, J.F., and Lajoie K.R., 1975, Map showing maximum earthquake intensity predicted in the southern San Francisco Bay region, California, for large earthquakes on the San Andreas and Hayward faults: U.S. Geological Survey Miscellaneous Field Studies Map MF-709, scale $1: 125,000$.

Brabb, E.E., and Pampeyan, E.H., compilers, 1983, Geologic map of San Mateo County, California: U.S. Geological Survey Miscellaneous Investigations Series Map 1-1257-A, scale 1:62,500.

California Division of Mines and Geology, 1974 to 1983, State of California Special Studies Zones Act quadrangles [Altamont, 1982; Annapolis, 1974; Ano Nuevo, 1982; Antioch North, 1976; Antioch South, 1976; Arched Rock, 1974; Asti, 1983, 1976; Bodega Head, 1974; Bolinas, 1974; Byron Hot Springs, 1982; Calaveras Reservoir, 1982; Castle Rock Ridge, 1974; Cedar Mountain, 1982; Chittenden, 1982; Clayton, 1974; Cordelia, 1983; Cotati, 1983, 1976; Cuttings Wharf, 1983; Cupertino, 1974; Diablo, 1982, 1974; Double Point, 1974; Dublin, 1982, 1974; Duncan Mills, 1974; Eylar Mountain, 1982; Fairfield South, 1974; Fort Ross, 1974; Franklin Point, 1982; Geyserville, 1983, 1976; Gilroy, 1982, 1974; Gilroy Hot Springs, 1982; Glen Ellen, 1983, 1976; Gualala, 1974; Half Moon Bay, 1976; Hayward, 1982; Healdsburg, 1983, 1976; Inverness, 1974; Jericho Valley, 1983; Jimtown, 1983, 1976; Knoxville, 1983; La Costa Valley, 1982; La Honda, 1974; Laurel, 1976; Lick Observatory, 1982, 1974; Livermore, 1982; Loma Prieta, 1976; Los Gatos, 1976; Mare Island, 1982; Mark West Springs, 1983, 1976; Mindego Hill, 1974; Midway, 1982; Milpitas, 1982; Montara Mountain, 1982, 1974; Morgan Hill, 1982, 1974; Mount Day, 1982; Mount George, 1983; Mount Madonna, 1976; Mount St Helena, 1983; Mount Sizer, 1982, 1974; Newark, 1982; Niles, 1980; Oakland East, 1982; Oakland West, 1982; Ornbaun Valley Southwest, 1974; Palo Alto, 1974; Petaluma River, 1983, 1976; Plantation, 1974; Point Reyes Northeast, 1974; Port Chicago, 1977; 
Richmond, 1982; San Felipe, 1982; San Francisco South, 1982, 1974; San Gregorio, 1976; San Jose East, 1982, 1974; San Leandro, 1982; San Mateo, 1974; Santa Rosa, 1983, 1976; Sears Point, 1983, 1976; Stewarts Point, 1974; Tassajara, 1982; Tomales, 1974; Valley Ford, 1974; Walnut Creek, 1974; Watsonville East, 1982; Watsonville West, 1976; Woodside, 1974]: scale 1:24,000.

Fumal, T.E., 1978, Correlations between seismic wave velocities and physical properties of near-surface geologic materials in the southern San Francisco Bay region, California: U.S. Geological Survey Open-File Report 78-1067, $52 \mathrm{p}$.

Green, H.G., Lee, W.H.K., McCulloch, D.S., and Brabb, E.E., 1973, Faults and earthquakes in the Monterey Bay region, California: U.S. Geological Survey Miscellaneous Field Studies Map MF-518, scale 1:200,000.

Greensfelder, R.W., 1974, Maximum credible rock acceleration from earthquakes in California: California Division of Mines and Geology Map Sheet 23, 12 p., scale 1:2,500,000.

Hall, N.T., Sarna-Wojcicki, A.M., and Dupre, W.R., 1974, Faults and their potential hazards in Santa Cruz County, California: U.S. Geological Survey Miscellaneous Field Studies Map MF-626, scale $1: 62,500$

Helley, E.J., and Herd, D.G., 1977, Map showing faults with Quaternary displacement, northeastern San Francisco Bay region, California: U.S. Geological Survey Miscellaneous Field Studies Map MF-881, scale 1:125,000.

Herd, D.G., 1977, Geologic map of the Las Positas, Greenville, and Verona faults, eastern Alameda County, California: U.S. Geological Survey OpenFile Report 77-689, 25 p., scale 1:24,000.

$1978 \mathrm{a}$, Neotectonic framework of central coastal California and its implication to microzonation of the San Francisco Bay region, in Proceedings of the Second International Conference on Microzonation for Safer Construction-Research and Application, San Francisco, 1978: v. 1, p. 238. $1978 \mathrm{~b}$, Map of Quaternary faulting along the northern Calaveras fault zone, Las Trampas Ridge, Diablo, Dublin, Niles, and La Costa Valley 7.5minute quadrangles, California: U.S. Geological Survey Open-File Report 78-307, scale 1:24,000.

Herd, D.G., and Helley, E.J., 1977, Fauits with Quaternary displacement, northwestern San Francisco Bay region, California: U.S. Geological Survey Miscellaneous Field Studies Map MF-818, scale 1:125,000.

Jennings, C.W., 1975, Fault map of California with locations of volcanoes, thermal springs, and thermal wells: California Division of Mines and Geology, Geologic Data Map 1, scale 1:750,000.

Laird, R.T., Perkins, J.B., Bainbridge, D.A., Baker, J.B., Boyd, R.T., Huntsman, Daniel, Staub, P.E., and Zucker, M.B., 1979, Quantitative land-capability analysis: U.S. Geological Survey Professional Paper 945, $115 \mathrm{p}$.

McClure, F.E., 1973, Performance of single family dwellings in the San Fernando earthquake of February 9, 1971: U.S. Department of Housing and Urban Development and U.S. National Oceanic and Atmospheric Administration, 139 p.

Page, R.A., Blume, J.A., and Joyner, W.B., 1975 ,
Earthquake shaking and damage to buildings: Science, v. 189, no. 4203, p. 601-608.

Prescott, W.H., and Burford, R.O., 1976, Slip on the Sargent fault: Seismological Society of America. Bulletin, v. 66, p. 1013-1016.

Rinehart, W.A., Algermissen, S.T., and Gibbons, Mary, 1976, Estimation of earthquake losses to single family dwellings: U.S. Geological Survey, 198 p. [available from National Technical Information Service, U.S. Department of Commerce, Springfield, VA 22161 as NTIS PB-251-677/AS].

Santa Clara County, 1978, Relative seismic-stability map: San Jose, California, scale 1:60,000. [revised from California Division of Mines and Geology, 1974, Relative seismic-stability map: California Division of Mines and Geology Special Report 107].

Scholl, R.E., 1974a, Statistical analysis of low-rise building damage caused by the San Fernando earthquake: Seismological Society of America Bulletin, v. 64, no. 1, p. 1-23.

1974b, Low-rise building damage from lowamplitude ground motions: Seismological Society of America Bulletin, v. 64, no. 6, p. 1743-1755.

Scholl, R.E., and Farhoomand, Iraj, 1973, Statistical correlation of observed ground motion with low-rise building damage: Seismological Society of America Bulletin, v. 63, no. 5, p. 1515-1537.

Slemmons, D.B., 1977, State-of-the-art for assessing earthquake hazards in the United States, report 6, faults and earthquake magnitude: U.S. Army Engineer Waterways Experiment Station Miscellaneous Paper S-73-1, 166 p. in various pagings.

Sorg, D.H., and McLaughlin, R.J., 1975, Geologic map of the Sargent-Berrocal fault zone between Los Gatos and Los Altos Hills, Santa Clara County, California: U.S. Geological Survey Miscellaneous Field Studies Map MF-643, scale 1:24,000.

Steinbrugge, K.V., Cloud, W.K., and Scott, N.H., 197.0, The Santa Rosa, California, earthquakes of October 1, 1969: Washington, D. C., U.S. Coast and Geodetic Survey, 99 p.

Steinbrugge, K.V., McClure, F.E., and Snow, A.J., 1969, Studies in seismicity and earthquake damage statistics, 1969, appendix A: U.S. Coast and Geodetic Survey, $142 \mathrm{p}$.

U.S. Coast and Geodetic Survey, 1969, Studies in seismicity and earthquake damage statistics, 1969 summary and recommendations: U.S. Coast and Geodetic Survey, 23 p.

U.S. Geological Survey, 1978, Land use and land cover maps for San Francisco South, Hunters Point, San Leandro, Montara Mountain, San Mateo, Redwood Point, Newark, Half Moon Bay, Woodside, Palo Alto, Mountain View, San Gregorio, La Honda, Mindego Hill, Pigeon Point, Franklin Point, Big Basin, and Ano Nuevo quadrangles, California: U.S. Geological Survey Open-File Reports, $78-738$ to $78-755$, scale $1: 24,000$.

Wesson, R.L., Helley, E.J., Lajoie, K.R., and Wentworth, C.M., 1975, Faults and future earthquakes, in Borcherdt, R.D., ed., Studies for seismic zonation of the San Francisco Bay region: U.S. Geological Survey Professional Paper 941-A, p. A4-A30.

Wood, H.O., 1908, Distribution of apparent intensity in San Francisco, in Lawson, A. C., and others, The 
California earthquake of April 18, 1906: report of the State Earthquake Investigation Commission: Carnegie Institute of Washington Publication 87, v. 1, p. $220-245$.
Wood, H.O., and Neumann, Frank, 1931, Modified Mercali intensity scale of 1931: Seismological Society of America Bulletin, v. 21, p. 277-283. 